\title{
Monitoring of arsenic in groundwater of adjoining areas of Gorakhpur District (U.P.), India.
}

Vira Tripathi and Anil Kumar Dwiwedi*

Pollution and Environmental Assay Research Laboratory (PEARL),

Department of Botany, D.D.U. Gorakhpur University, Gorakhpur-273009, U.P. India.

Received: 2/19/2018; Revised: 2/23/2018; Accepted: 3/25/2018

\begin{abstract}
Arsenic contamination is an enormous worldwide problem. Groundwater arsenic contamination and sufferings of people have been reported in 20 countries in different parts of the world. The magnitude is considered highest in 5 Asian countries and the severity is in order of Bangladesh> India > Mangolia > China > Taiwan. The contamination of drinking water supplies with natural Occurring arsenic is major health problem. The paper deals estimation of arsenic in groundwater of Gorakhpur district. For this purpose, total 36 study sites were selected in urban as well as in rural area of the district, further the samples were collected from shallow bore well as from the deep bore wells. It was concluded that 5 areas are under high risk zone of arsenic, 5 areas are at the low risk and 26 areas which are monitored are in the safe zone of arsenic. High risk areas are crossing the permissible level of arsenic consumption according to $\mathrm{WHO}$
\end{abstract}

Key words: Arsenic, high risk zone, Gorakhpur, groundwater, water

\section{Introduction}

Naturally occurring arsenic contamination of groundwater presents a serious threat to public health. Most parts of India is facing anthropogenic ground water pollution which is mainly enrichment of various chemical parameters such as nitrates, hardness, metallic trace element and micro biological organisms. The overexploitation of groundwater in some countries include water quality degradation, untreated industrial effluents is main reason of severe groundwater and surface water pollution.

First underground water zone is situated at 6-8 $\mathrm{mt}$ depth from the surface while second is between 22$34 \mathrm{mt}$ third and fourth layer of aquifers are at depth of 40-46 $\mathrm{mt}$ and $60-80 \mathrm{mt}$ from the surface respectively. The domestic hand pumps draw the water of the first or second layer of aquifer whereas the India mark II hand pumps are bored up to third layer of aquifer. It is obvious that water of the first layer is contaminated due to the infiltration of polluted water accumulated in the lakes and depression areas, while the water third and fourth layer has the chances of contamination of arsenic. Verma S.S. et al., (2009)

\section{Material and Methods}

\section{Study sites}

For detection of arsenic mainly 36 study sites were selected, which include rural as well as urban areas which is mentioned below. The study sites are indicated in figure no 1.

\footnotetext{
${ }^{*}$ Corresponding Author:

Anil K. Dwivedi,

PEARL, Department of Botany,

DDU Gorakhpur University,

Gorakhpur- 273009, India.

E-mail: araudr@gmail.com
}

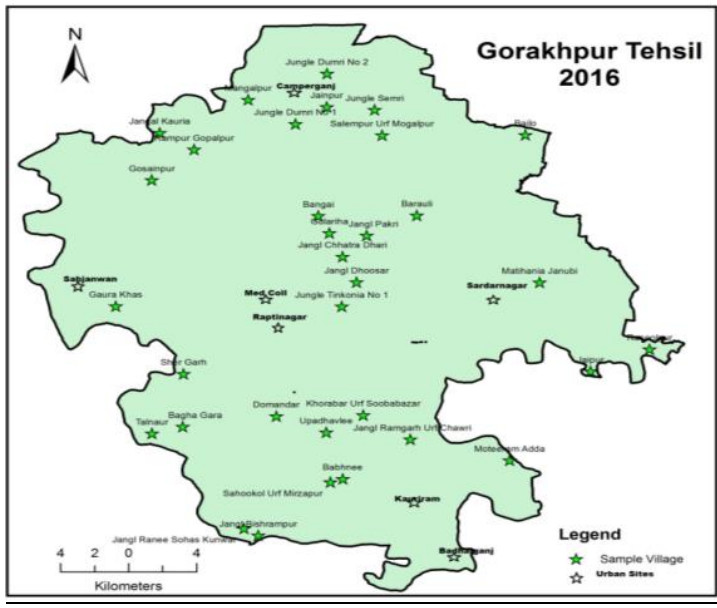

Figure 1. study sites for collection of water samples

The water which was collected from these sites were from shallow water and India mark II hand pumps in different bottles. The testing was done differently in both the waters. Precautionary conditions before taking this water was that the hand pump from which groundwater has been taken should be India mark $\mathrm{ll}$ as per jal nigam. The water sample collected from selected sites were taken in a plastic and glass bottles with safe and clean handed and was tested in" Environment and pearl assay laboratory" D.D.U Gorakhpur university, Gorakhpur, for arsenic determination. The sample were collected during summer season in the month of June till August (2016). Water samples were collected during summer because during this season the water table lowers. Tube wells were 
operated at least 10 minutes before collection to flash out stagnant water inside the tube wells in order to get the fresh water. The reading was analysed by "wagtech digital arsenator" present in the laboratory. Arsenator has an arsenic detection range from $1 \mathrm{ppb}-500 \mathrm{ppb}$ (parts per billion).

\section{Result and Discussion}

For the ease of understanding the findings of arsenic concentration in the samples of groundwater it is classified under three categories which is indicated below

1. Acceptable Range $(<1$ to $<5 \mathrm{ppb})$

2. Moderate Range (5-10ppb)

3. High Range $(>50 \mathrm{ppb})$ concentration of arsenic

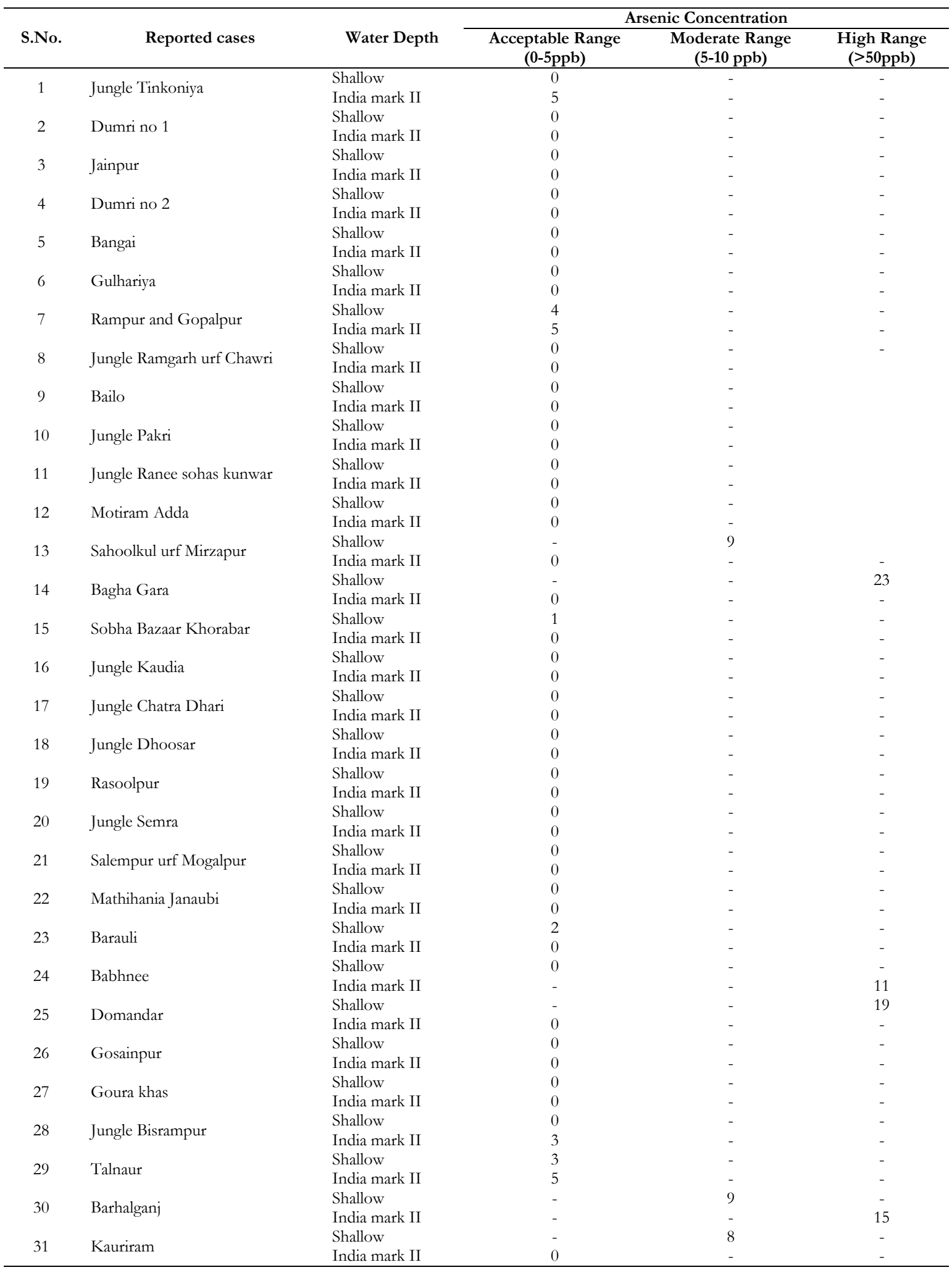




\begin{tabular}{|c|c|c|c|c|c|}
\hline \multirow{2}{*}{32} & \multirow{2}{*}{ Sardarnagar } & Shallow & 0 & - & - \\
\hline & & India mark II & 0 & - & - \\
\hline \multirow{2}{*}{33} & \multirow{2}{*}{ Medical college } & Shallow & 0 & - & - \\
\hline & & India mark II & 0 & - & - \\
\hline \multirow{2}{*}{34} & \multirow{2}{*}{ Sahjanva } & Shallow & - & 7 & - \\
\hline & & India mark II & 0 & - & - \\
\hline \multirow{2}{*}{35} & \multirow{2}{*}{ Campierganj } & Shallow & - & 9 & - \\
\hline & & India mark II & 0 & - & - \\
\hline \multirow{2}{*}{36} & \multirow{2}{*}{ Raptinagar } & Shallow & - & - & 13 \\
\hline & & India mark II & 0 & - & - \\
\hline
\end{tabular}

On assessment of arsenic in adjoining area of Gorakhpur it was concluded that most of the area are under safe zone, some area such as Campierganj, Sahjanva, kauriram, barhalganj (shallow) sahoolkul urf Mirzapur are of moderate range of arsenic consumption and only few area (Bagha Gara, Domandar, Barhalganj (India mark), Raptinagar, Babhnee) are under high risk and crossing the permissible level of arsenic consumption according to WHO that is $10 \mathrm{ug} / 1$. Thus, it can be concluded that most of the area are under arsenic free zone. It was also concluded by this survey that shallow water are more likely to be arsenic polluted than the India mark II hand pumps. Most of the shallow water are arsenic rich as compared to the India mark II hand pumps.

\section{Recommendations and Conclusion}

This paper has attempted to summarize the incidents of arsenic contamination in groundwater in adjoining area of Gorakhpur and as a result as far now major 5 blocks are under major threat of arsenic. It is necessary for the Government to take a serious act on it by awaring the people living in high zone of arsenic. They should be aware of the serious and major causes of arsenic on longer exposure.

The hand pumps should be indicated by red colour indicating that the water is not safe for drinking purpose. Testing kits should be provided to the local people living in that area at reasonable cost or cost-effective method or any biological plants must be used for arsenic phytoremediation. The data should be collected around the Gorakhpur city of arsenic free and arsenic zone areas and the installation of arsenic kit should be done.

Shallow water is more likely to be arsenic contaminated as compared to India mark II the reason may be that tube wells installed in shallow aquifers may be not as deep as India mark II tube wells and it can also be stated from the above conclusion that as the deepness of the tube wells is increasing the contamination rate is decreasing. Bhatia S et al., (2014) also supported this according to his work done on arsenic detection in Bihar state revealed that more than $50 \%$ of the hand-pumps having arsenic greater than $200 \mathrm{ppb}$ were private owned and lying in the shallow aquifer zone of 15$35 \mathrm{~m}$. This finding is similar to other studies in West Bengal and Bangladesh (Smith et al., 2003 and Ahmed et al., 2011) they supported that private owned installed tube wells are more prone to arsenic contamination. Kumar S et al., (2011) also supported in his paper that arsenic comes in to water by oxidation theory which is more acceptable till date than oxyhydroxide reduction theory. According to the reduction theory, arsenic is released from the sulfide minerals (arseno-pyrite) in the shallow aquifer due to oxidation.

There is no exact range of the installation of private colonizers tube wells, maybe they are not as deep asindia mark tube wells. More work should be done on such findings and exact data should be collected and wide research is required in this field.

\section{References}

1. Kumar S, Pandey. G, Sharma. A, “Assessment of Arsenic in Groundwater in Gorakhpur District, Uttar Pradesh, India ${ }^{e e}$ M. Tech. Dissertation, Department of Civil Engineering, M. M. M. Engineering College, Gorakhpur, U.P., India (2011):766-770

2. Verma S.S. and Singh V.K. "Ramgarh Tal; A Dwindling Natural Hritage," in A.K. Dubey \& A.K. Pandey (Eds) Archaeological and Cultural Heritage of Purvanchal, Pratibha Prakashan, Delhi, (2009): 437-454.

3. Verma S.S. "Urban Land Use Inventory: Through Aerial Photo Interpretation Technique" Shivaya Publication, Gorakhpur, U.P., India, (1986): 5

4. Srivastava S, Dwivedi A.K "Biological Wastes: The Tool for Biosorption of Arsenic." J Bioremed \& Biodeg 7.1 (2015): 323.

5. Dwivedi AK, Srivastava S, Dwivedi S, Tripathi V. "Natural Bio-Remediation of Arsenic Contamination: A Short Review." Hydrology: Current Research. 6.1 (2015): 186.

6. Dwivedi, A.K. "Arsenic in Groundwater: An Issue Beyond Boundary" In: Biodiversity Conservation \&amp; Sustainable Development (Ed. S. Domonic Rajkumar and J.K. Lal), Centre for Biological Research, Puthalam, Tamil Nadu, India: (2013): 30-43. 
7. Smith M. M. H., Timir H., Protap C., 9. Bhatia S, Balamurgan G, Baranwal A. "High Chakraborty D. K., Xavier S., and Smith, A. H. "A dugwell program to provide arsenic-safe water in West Bengal, India: preliminary results." J. Environ. Sci. Health A Tox. Hazard. Subst. Environ. Eng. A38, (2003): 289-299.

8. Ahmed A. A., Alam M. J. B., and Ahmed, A. M. "Evaluation of socio-economic impact of arsenic contamination in Bangladesh." J. Toxicol. Environ. Health Sci. 3 (2011): 298-307. arsenic contamination in drinking water handpumps in Khap Tola, West Champaran, Bihar, India Front. Environ.”(2014). Sci https://doi.org/10.3389/fenvs.2014.00049.

\section{Cite this article as:}

Vira Tripathi and Anil K. Dwiwedi. Monitoring of arsenic in groundwater of adjoining areas of Gorakhpur District (U.P.), India. Annals of Plant Sciences 7.4 (2018) pp. 2205-2208.

do $\mathrm{http://dx.doi.org/10.21746/aps.2018.7.4.23}$ 